\title{
Text Paradigm of Derivative Prepositions 'in connection with' in the Russian Language
}

\author{
Ekaterina Zvereva, Kamo Chilingaryan*
}

Department of Foreign Languages, Institute of Law, RUDN University (Peoples' Friendship University of Russia), Russian Federation

Copyright $\mathrm{C} 2019$ by authors, all rights reserved. Authors agree that this article remains permanently open access under the terms of the Creative Commons Attribution License 4.0 International License

\begin{abstract}
The issue of functioning of derived prepositions in modern speech is of special interest for linguists, since the semantic and behavioral features of these words are less studied than their formal characteristics. In addition, prepositions not only exist in the system of parts of speech, but also in linguistics used to be seen as 'empty words' in the sense that no special studies of the functional and semantic features of a preposition were conducted in linguistics: prepositions were studied as a whole, as a class of words. In many respects this is due to the fact that special approaches are required for their study, taking into account the specifics of this syncategorematic word, which includes not only words of different structures, but also transitional forms, different in time of occurrence and degree of receiving a preposition.
\end{abstract}

Keywords Derived Prepositions, Derivative, Objective Phrases, Speech Units, Textual Paradigm

\section{Introduction}

At present there is a scientific theory of the preposition, and it is possible to single out separate stages of its formation. Each of them can be described by a certain aspect of the study of the preposition. Thus, in the linguistics of the XIX century, the category of the preposition was generally understood, the essential features of this part of speech were singled out, the composition of the prepositions was studied, their structural functions were examined. In linguistics of the 20 th century, one of the main questions is the lexical meaning of prepositions, which was never solved unambiguously. The lack of a common opinion on this issue makes it difficult to study prepositions in general and their semantic features, in particular. Because of the complex composition of Russian prepositions, the differential features of prepositions have been studied since the middle of the 20th century; various classifications of prepositions are being proposed (by origin, structure, presence or absence of meaning in the preposition). However, many of the prepositional units did not find their exact place in these classifications. At the same time scholars began a purposeful study of the service functions and syntactic relations of prepositions, as well as the semantic relations expressed by them within the framework of the phrase and sentence. The second half of the 20th century saw the consideration of problems of derivative prepositions: conditions under which different parts of speech shift to prepositions, the mechanism for the formation of derivative prepositions was studied, criteria for distinguishing the preposition and the homonymous form of the significant words were elaborated. Problems associated with the study of derivative prepositions remain relevant for linguistics at the beginning of the 21 st century. Various studies have appeared in which prepositions are considered in the diachronic / synchronic, structural / functional, semantic / formal aspects (Andreevskaya, 2007; Vinogradova, Chekalin, 2007; Vsevolodova, 2010; Galaktionova, 2007; Eremin, 2010; Klobukov, 2007; Lebedeva, 2007; and etc.).

Attention to derivative propositions in the past decades is explained not only by their active use in speech, but also by the fact that they continue to be replenished at the expense of resources of full words (mainly due to prepositional and objective combinations of nouns: в связи (v svyazi) in connection, в случаe (v sluche) in the case, в расчете на (v raschete na) counting on, с иелью (s tselyu) with the purpose, etc.). This replenishment is explained not only by linguistic factors, but also by the needs of communicants in the more precise differentiation of semantic relationships and relations expressed in the utterance. Active processes of grammaticalization of the forms of full words preconditioned the specificity of use of the Russian prepositions, including not only words of different structure, but also transitional forms, different in time of occurrence and degree of receiving prepositions. Due to this fact the problem of verifying derivative prepositions remains open until now (Vsevolodova, 2005, 2010; Vinogradova, 2004, 2006; Eremin, 2010; Pankov, 2004; Sheremetyeva, 2007, 2008). 
Modern researchers still face the task to determine the status and place of derivatives of prepositions and objective phrases among other parts of the speech, to investigate the influence of the lexical meaning of the basic noun on semantics and the functioning of derived prepositions, and also to clarify the criteria allowing to determine the completeness of the shift of a noun into a preposition. In addition, the study of the interaction of prepositions with other linguistic units, the study of the positional possibilities of prepositions, the analysis of the communicative status, the stylistic and pragmatic functions of prepositions is of interest. With all the diversity of the works presented and the large number of studies conducted, there remain issues that need to be addressed. Among the issues we will mention: the question of the presence of lexical meaning in prepositions remains unanswered, the composition of prepositional units is controversial, prepositions are not fully represented and described in lexicographical literature, and behavioral characteristics of derivative prepositions in various syntactic conditions have not been fully studied.

\subsection{Novelty}

All the above said determines the relevance of the research topic. A comprehensive study of the speech relevance of structures with derivative prepositions and correlative substantive-definitive combinations is closely connected with the problems outlined above, since it is oriented toward revealing the regularities in the formation of the semantics of derivative prepositions, their structural and communicative functions in the text, their syntagmatic potential, including the compatibility potential with anaphoric pronouns. The urgency of the work is also determined by the fact that its topic is directly related to the study and description of the text paradigm of the preposition, which refers to 'possible realizations of the prepositional unit in the text' (Vsevolodova, 2005) including the set of stable expressions formed on the basis of the preposition. The concept of the "textual paradigm of the preposition" makes it possible to describe the behavioral features of prepositions, explicated in speech and conditioned by certain con-situational conditions. A multifaceted study of speech behavior of equivalent prepositional-case and substantive-definitive combinations of в свете этой реальности - в этом свете ( $v$ svete etoy realnosti-v etom svete), по причине этого соглашения по этой причине (po prichine etogo soglasheniya- po etoy prichine), в отночении этого сотрудничества - 6 этом отношении (v otnoshenii etogo sotrudnichestva $-\mathrm{v}$ etom otnoshenii) 'in the light of this reality / in light of it'; 'for the reason of this agreement / for this reason'; 'with respect to this cooperation / in this respect' is, from our point of view, an important task because it sheds light on the complex historical interrelations of a preposition and noun. Finally, it is important to study the trends in the development of the Russian language, and the topic of this paper is related to the question of the prospects of competing speech units, which are actively used in the modern speech.

\subsection{Object / Subject and Purpose of the Research}

The object of the study are the denominative derivative prepositions, in particular the preposition 'in connection with' and the prepositional combinations formed on its basis, functioning as means of cohesion (в связи с этим, (самостоятельный оборот речи) v svyazi s etim - [an independent speech construction]- 'in connection with this'; в связи с этим (этой)- v svyazi s etim (etoy) - 'in connection with this' plus the noun in the ablative case'; « 6 связи с этим вопросом» $v$ svyazi s etim voprosom - 'in connection with this question', «в связи с этой проблемой» - $v$ svyazi s etoy problemoy - 'in connection with this problem' and pronominal-defining phrases with basic nouns for prepositions в этой связи (v etoy svyazi) 'in this regard', which are functional and semantic equivalents of the indicated prepositional-case combinations and compete with them in speech. The subject of the research is synchronous-diachronic factors, which determine the structural specifics of the above units, the conditions of their speech conflict and the trend of use in the modern speech. The source of the factual material was the texts of the late XX and early XXI century obtained by the authors from various sources. During the research the authors used examples, from TV and radio broadcasts. The purpose of the research is to identify and describe the prerequisites, conditions and tendencies of the speech conflict of prepositional-case combinations of в связи с этим, (v svyazi s etim) - 'in connection with this', в связи с этим (этой) - (v svyazi s etim) 'in connection with this' plus the noun in the ablative case and their functional-semantic equivalent $в$ этой связи (v etoy svyazi) - 'in this regard'.

The criterion that guided the authors in their choice of material is the fact that these prepositional and objective phrases and derivative prepositions can be found in both oral and written text, however, exceeding in written one.

\subsection{Tasks}

In accordance with the purpose of the research, the following tasks were set:

- to show the specificity of the derivative preposition as a lexical unit of the system of parts of modern Russian speech;

- to characterize the structural-semantic and communicative-pragmatic functions of prepositions in the text;

- consider the historical conditions for the formation of a derivative preposition в связи с (v svyazi s) 'in connection with'; 
- to reveal the semantic features and conditions for the use of ligamentous structures formed on the basis of this derivative preposition;

- describe the semantics and peculiarities of functioning of the substantive-defining phrase в этой связи (v etoy svyazi) - 'in this regard';

- describe the conditions of conflict of prepositional-case combinations в связи с этим (v svyazi s etim) -'in connection with this', в связи с этим (этой) - (v svyazi s etim (etoy), - 'in connection with this' plus the noun in the ablative case and their functional-semantic equivalent в этой связи (v etoy svyazi) - 'in this regard' in the modern speech;

- to identify trends in the use of competing prepositional and case-specific ligamentous constructions of speech.

\section{Methodology}

To achieve the goal and solve the set problems the following research methods were used: descriptive method, lexicographic analysis method, component analysis method, comparative method, structural-semantic and semantic-stylistic methods. In addition, various methods were used: observation, information obtaining, comparison, interpretation, generalization.

The theoretical significance of the research is that the results of the research contribute to the development of the concept of the 'textual paradigm of the preposition'; deepen the notion of the combining properties of the preposition with anaphoric pronouns; clarify the existing ideas about semantic features of the prepositional units; contribute to the development of criteria for distinguishing between a preposition and a non-preposition, thereby contributing to a further comprehension of the specific nature of the lexical meaning of the preposition. The refinement of the degree of grammaticalization of specific relational constructions and identification of additional means for solving this problem also has theoretical significance. Finally, a comparative study of the semantics of prepositional-case combinations and their substantive-definitive equivalents makes it possible to amend the representation of the corresponding units in lexicographic sources. The practical significance of the research is that the results obtained can be applied in the practice of school and university teaching of the Russian language while studying prepositions as a class of functional words, their functions and methods of replenishment. The materials of the work can also be used in lexicographic practice in compiling vocabulary articles describing prepositional and nominal ligamentous speech constructions. Knowledge of the properties of derivative prepositions and the stable ligamentous constructions formed on their basis is of a great practical importance for the study of the Russian language as a foreign language. In addition, the research materials can serve as a basis for a comparative study of other stable prepositional-case combinations with an anaphoric pronoun and their functional and semantic equivalents.

A short excursion into the Russian grammar shows that prepositions as a separate part of speech were formed in the early Russian grammar along with the nouns, pronouns, adverbs and other classes of words. The functions and nature of the lexical meaning determine the specifics of the preposition, which means the following: first, there are many definitions of the preposition in the Russian language, and yet all linguists converge in one thing: it is a functional part of speech or 'non-notional, formal' words (Shmykalova, 2015: 17). In other words, prepositions possess signs of service words, to which V. Vinogradov relates: 1) the absence of the nominative value if used independently; 2) the impossibility of considering a preposition from the point of view of self-propagation of a syntagma, or a phrase; 3 ) the absence of a pause after the pronunciation of this part of speech (without special expressive justification); 4) morphological indivisibility or semantic indecomposability; 5) the absence of a phrasal stress (except in contrast cases); 6) the absence of an independent stress on most of the primitive words of this type; 7) the uniqueness of grammatical meanings that dissolve in themselves the lexical content of functional words (Vinogradov, 2001: 33).

Second, the preposition is the binding component in the sentence, and the main function of the preposition is determined by its binding meaning: the preposition correlates the indirect cases of nouns (as well as substantivized adjectives, pronouns and numerals) with a specific word or sentence, thereby expressing diverse relationships between the forms of the noun and other parts of speech in the sentence (Valgina, Rosental, Fomina, 2003: 333). Acting as a binding element, the preposition characterizes the typical semantic relationship between the substantive case form and the main component. V. Vinogradov emphasizes that prepositions as speech particles convey the semantic meaning of spatial, temporal, causal, objective, possessive, restrictive and other relations between objects or the same relations of objects to actions, states and qualities. From the point of view of syntactic meaning, preposition denotes the relationship between the forms of indirect cases of nouns, pronouns or substantivized adjectives and numerals on the one hand, and verbs, nouns, pronouns, adjectives (rarely adverbs), on the other hand (Vinogradov, 2004: 555).

Thirdly, the binding function of the preposition determines its specific syntactic property - a two-sided syntactic connection, that is, an inversion, both to the ruling and to the controlled component. In the 'Russian grammar' it is noted that by combining two words, the preposition as a grammatical unit is simultaneously addressed to both of them; this tendency is observed, first of all, with strong and regularly predictable weak syntactic links (Russian 
grammar, vol. I: 365). Ya. Lebedeva adds that a closer connection is formed with words that have objective meaning (nouns, pronouns, numerals, pronoun-numerals): as a result of this combination, a prepositional word form is formed (Lebedeva 2007: 281). I. Shmykalova focuses her attention on the duality of syntactic transformations, denoted by prepositions in the sentence: on the one hand, grammatical dependence of the case form of one significant word (noun or its equivalent) on another significant word or combination of words is traced; and on the other hand, it is the sense relation between these words, formed as a result of a complex interaction of the lexical meanings of full-valued words, the semantics of the preposition and the case semantics (Shmykalova, 2015: 17).

Fourthly, the peculiarity of the preposition is the uniqueness of its lexical meaning. The question of the lexical meaning of prepositions, however, did not find an unambiguous answer from the philologists. According to the first point of view, widespread among contemporary linguistic society, most of the prepositions have a lexical and grammatical meaning, with the note that the content of the lexical meaning of all prepositions is ambiguous (Vinogradov, 2001, Vsevolodova, 2008). V. Pekar cites the following argument in favor of the position according to which prepositions possess a lexical meaning: 1 . The semantics of relativity in prepositions finds its significance not only at the grammatical level, but also at the lexical level. As the category of relation is traced in the meanings of full-valued words - the terms of kinship; nouns, denoting parts and the whole; of all predicate words,- then the assertion that for preposition only the grammatical meaning is characteristic - to a certain extent is not indisputable. 2. When the spatial or temporal preposition is changed, the content of the sentence is distorted. Temporal and spatial prepositions reflect the relation of objects in reality, thereby confirming their lexical meaning. Here is an example: Книга на шкафу (Kniga na shkafu). - 'The book is on the bookcase'. - Книга под шкафом (Kniga pod shkafom) 'The book is under the bookcase'. When the spatial preposition is changed, the content of the sentence itself is fundamentally distorted. Consequently, the relations between objects determined by prepositions can also be regarded as phenomena of extra linguistic reality. 3 . Prepositions perform a nominative function, since some words are not self-sufficient for use in the form of independent elements in the sentence, fully exercising their nominal function. For example, transitive verbs are not used without any objects, where a preposition can also act as an object. Hence, prepositions enter into relations with other words, both paradigmatic and syntagmatic semantic, which indicates the inclusion of prepositions in the semantic system of the language. (Pekar, 2000: 16). According to V. Vinogradov, who holds to the point about the lexical meaning of prepositions, the degree of their formality, abstractness and lexical weight may be different.
The authors draw attention to the fact that there are so-called weak, that is, 'empty' prepositions used in some syntactic word combinations in the meaning of a purely grammatical case relation, as well as prepositions preserving the brightness of their lexical meaning, and forming in combination with nouns, 'a separate syntagma that discovers a certain independence and only adjoins other members of the sentence' (Vinogradov, 2001: 556). The opposite point of view is the recognition of prepositions bearing only formal, grammatical meaning and denying the existence of lexical meaning (Shakhmatov, Peshkovsky). The position of these scholars is based on the fact that the semantic category of the relationship finds its realization only on the grammatical level of the language. Many researchers explain the lack of the lexical meaning in the preposition by its inability to act as an independent element, that is, as a member of the sentence. Thus, according to I. Meshchaninov, 'instead of lexical meaning, prepositions contain an indication of the syntactic connection between the members of the sentence.' And further: 'they never take an independent position and can never act as an independent member of the sentence or as a constituent part of it with its integral lexical-syntactic content' (Meshchaninov 1978: 256-357). The last argument is controversial. According to I. Shmykalova, the loss of the role of an independent member of the sentence is a sign of lexical 'devastation' of the word, its grammaticalization, strengthening of its structural functions to the detriment of its nominative ones (Shmykalova 2015: 18).

Fifth, in the question of the grammatical meaning of a preposition, as well as its lexical meaning, there is no unity of opinions. Not all researchers, like V. Vinogradov, are inclined to associate the lexical and grammatical meanings of the preposition. For example, E. Cherkasova notes the discrepancy between the lexical and grammatical meanings of the preposition. The researcher writes that, unlike the grammatical meanings of prepositions, which contain a generalized indication of the general nature of the syntactic relations between words (subordinate connection), and the lexical meanings of prepositions determine the nature of the semantic relations (Cherkasova, 1967: 12). Shmykalova emphasizes that the grammatical meaning of the preposition consists of, firstly, the subordination of the case form to the main word, and secondly, in the meaning of a certain indirect case of the noun (Shmykalova, 2015: 18). S. Galstyan, answering the question what in the preposition can be attributed to the lexical meaning, and what - to the grammatical meaning, agrees with the opinion of N. Kravchenko, according to whom the lexical meaning of the preposition can be considered as a 'derivative of the grammatical', i.e., the semantics of the prepositions coincides with their 'significative function' (the function of expression of relations) (Kravchenko, 2001: 31). S. Galstyan comes to conclusion that the grammatical meaning of the preposition is that prepositions connect the 
units of the language among themselves. Lexical meaning, in its turn, is an expression of a particular kind of relationship by the preposition (Galstyan, 2015: 74).

Thus, on the basis of analysis of various theories and linguistic material, it can be concluded that the specificity of the preposition as a special part of speech is as follows: 1) the preposition is a functional part of speech that performs certain structural functions in the construction of the sentence, and is not an independent member of the sentence; 2 ) the main function of the preposition is binding, it is the means of controlling the case form of the noun (or its equivalent); 3) it possesses two-sided syntactic communication; has an abstract lexical meaning, similar to the grammatical meaning of case forms of a noun; it holds a preposition in relation to the controlled case form. In other words, the main attribute of the preposition is its syntactic connection with the case form of the noun (or its equivalent) and the function of the means of formation of a syntaxeme.

\section{Different Approaches to the Problem}

The problem of the ratio of lexical and grammatical meanings in the semantics of prepositions is still debatable. The grammatical meaning of the preposition is, first of all, in the fact that prepositions connect the units of the language. Lexical meaning is the expression by the preposition of a certain kind of relationship between words. It is important to study the lexical and grammatical meanings in the preposition as a set. The field of prepositions of the Russian language is constantly developing and replenishing, while attempts to generalize and systematize the available information about prepositions have been undertaken for a long time, since $\mathrm{M}$. Lomonosov. In connection with this, and also depending on the views and principles of scholars, several grounds for classification of prepositions are presented in the linguistic literature. M. Kiyamova, examining the criteria for differentiating variants of derivative prepositions, emphasizes the difficulty in determining the basis for differentiation. Some researchers consider the criteria for differentiation in general, from the point of view of primitive and derivative prepositions, others, on the other hand, argue that the study of this issue should be more thorough and more detailed, taking into account the criteria for distinguishing variants of derivative prepositions. (Kiyamova, 2016: 144). Considering such a criterion for the differentiation of primitive and derived prepositions, as a word-formative one, V. Bondarenko notes that non-derivative prepositions 'are really unproductive, because it is not clear to us what words they were produced from' (Bondarenko, 1961: 7). There are other criteria for distinguishing between non-derivative and derivative prepositions. Thus, some researchers focus on the syntactic conditions of functioning of prepositions, while others consider it more expedient to focus on their morphological characteristics. For example, in the 'Russian grammar' it is stated that 'primitive prepositions are combined into a small and not replenishing group of simple words' ('Russian grammar' 1980, vol. I: 365). M. Vsevolodova, on the contrary, suggests that the class of primitive prepositions can slowly expand 'by moving to the center of units that lose motivation' (Vsevolodova, 2008: 128). E. Prusakova notes that the process of systematization of all information about prepositions is difficult, because there is no generally accepted systematic approach to the study of this issue. In other words, the linguist in the process of researching derivative prepositions takes into account only a certain part of the whole, mainly relying on his own senses and intuition. This phenomenon is explained by the fact that derivative prepositions are a group of lexemes, which includes not even one hundred units, and while studying problems related to prepositions, it is impossible to take into account the diversity of this part of speech (Prusakova, 2002: 1).

In the modern Russian, as V. Gavrilenko states, the process of formation of new function words from the content words is undergoing. Among them, there are the so-called derivatives, or secondary prepositions that perform the same function as the non-derivative or primary prepositions (i.e., those that existed in the original system, for example: 'to, in, from', etc.). The prerequisites for the formation of such units are the tendency to analytism in the Russian language, the desire for compression in the speech, the metaphorization of the speech, the desire to refine the meanings of non-derivative prepositions (Gavrilenko 2013: 37). In this regard, as emphasized by M. Kiyamova, opposing points of view emerged in scientific society on the problem of relation of various prepositions to a group of primitives or derivatives in synchrony and diachrony. As an example, the author gives a preposition межdy (mezhdu) 'between', which in the 'Russian grammar', in the works of V. Vinogradova and V. Veselitsky is regarded as primitive preposition from the position of a synchronic approach, and in the work of A. Peshkovsky - as a derivative preposition from the standpoint of a diachronic approach (Kiyamova, 2016: 144). L. Boriaeva, investigating in detail the origin and functioning of derivative prepositions, pays attention to the distinctive features of the syntactic properties of derivative and non-derivative prepositions (Boriaeva, 2010: 105). The author points out that with a great deal of probability it can be said that the syntaxeme with the derived preposition depends on the verb (predicate) and is part of the predicate group: 1) to the secondary members of the sentence, introduced by the derivatives, only a morphological rather than a syntactic question is possible: Кроме соседа, ни с кем не знаком (кроме кого?) -Krome soseda, ni s kem ne znakom (krome kogo?). 'Except for the neighbor, I do not know anyone' (except for whom?). In such an interpretation, the use of a preposition with a substantive phrase is syntactically isolated and is not related to the 
realization of the syntactic valences of the verb (predicate). 2 ) when a combination of a derivative preposition with a nominal form is deployed into a predicative construction, another predicate is required instead of the original construction. In other words, the nominal group with a derivative preposition communicatively complicates the statement, introducing a second rheme (psychological predicate). Пришли все, кроме Ивана! Пришли все, Иван не пришёл. (Prishli vse, krome Ivana.Prishli vse, Ivan ne prishol). 'All came except for Ivan'! 'Everybody came, Ivan did not come'. 3) denominative prepositions, with the exception of spatial ones, are not used in elliptical constructions, i.e., in incomplete subordinate clauses, which, as a rule, consist of a conjunction and an adjective or a noun (with or without a preposition). Such subordinate clauses do not have one or two main members of the sentence: the predicate (or part of it) or the predicate and subject Cf: Он в смущении. (фраза имеет смысл) (On v smushchenii) - 'He is embarrassed' (the phrase has a sense) and Он кроме своего отношения (On krome svoego otnosheniya) - 'He, except for his attitude' (the sense is lost and the phrase is not understandable) (Boryayeva, 2010: 105). As a result, L. Boryayeva comes to conclusion that these patterns are explained by the specifics of the syntactic processes, as a result of which the relative words of derivative prepositions were formed (Boryayeva, 2010: 105).

\subsection{Connection / in Connection}

The complexity of functioning of derivative prepositions in the Russian language can be judged, in particular, by the example of the preposition в связи c (v svyazi s) 'in connection with', referring to the type of new prepositions and serving as a further basis for the formation of stable ligamentous constructions в связи с этим, (v svyazi s etim) - 'in connection with this', в связи с этим (этой) (v svyazi $s$ etim (etoy)) - in connection with this' plus the noun in the ablative case, в этой связи (v etoy svyazi) - 'in this regard'. Addressing to the dictionary articles we see the derivative preposition в связи с (v svyazi s) - 'in connection with', expressing the meaning 'as a result of something', 'depending on something', 'according to something' (Rogozhnikova, 1991: 69-70) was formed on the basis of the word связь (svyaz') 'connection'. The noun связь (svyaz') - 'connection' for a long time in the history of the Russian language has had ambiguous semantics, denoting 1) an adaptation (of wood or metal), fastening, fixing parts of a structure, buildings, etc., unity; 2) a group of buildings that make up one whole, set under one roof; 3) pl. tendons, ligaments; 4) pl. mutual relations, ties; 5) an obstacle, a lack of freedom; 6) pl. gallery, transition. The data of the dictionary, reflecting the Russian language of the 11th-17th centuries, indicate that the word 'connection' at that time had a predominantly specific semantics. In the XVIII century, the stable abstract meaning of this noun is formed:
«Связь ж. дђйствіе по знач. гл. [связать]. // Связь, по знач. гл. связаться, соединенье, скрђпа, сцђпленье, совокупленье, соотношенье, зависимость, причинное средство; // товарищество, дружба и знакомство, взаимныя дБла; // все, что собрано изъ различныхъ частей, но составляет одно» - 'Connection'. Feminine; Action: [to tie]. // Connection, [to get tied]; contact, communicate, scraping, socialization, copulation, correlation, dependence, causal agent; // partnership, friendship and acquaintance, reciprocal; // everything that is tied up from different parts, but is one' (The Dahl Dictionary 1994, Vol. 4: 92.

In the Russian language of the first half of the twentieth century, the meaning of 'association, interdependence, and predicament' becomes the main (primary) for the noun связь (svyaz') -'connection': '1) something that connects sth. with sth; attitude creating sth. common between sth, mutual dependence, predicament. ... e.g. «Связь науки и практической деятельности, связь теории и практики, их единство должно стать путеводной звездой партии пролетариата. Сталин. // Согласованность, стройность в соединении частей какого-н. изложения, изображения, построения. Между речами и действиями героя драмы очень мало связи» - 'Тhe connection between science and practice, theory and practice, their unity must become the guiding star for the party of proletariat. [Stalin]. // Consistency, harmony in the combination of parts of a presentation, image, construction. There is very little relations between the speeches and actions of the character of the drama' (Ushakov's Dictionary 2000, Vol. 4: 107-108). At present, according to thesaurus dictionaries, in the semantic paradigm of связь (svyaz') - 'connection//relation' there are 10 meanings, one of which served as a basis for the formation of the preposition в связи с (v svyazi s) - 'in connection with'. At the same time, the abstract meaning of predicament gradually comes to the forefront. (Small Academic Dictionary [MAC] 1999, Vol. 4: 58-59).

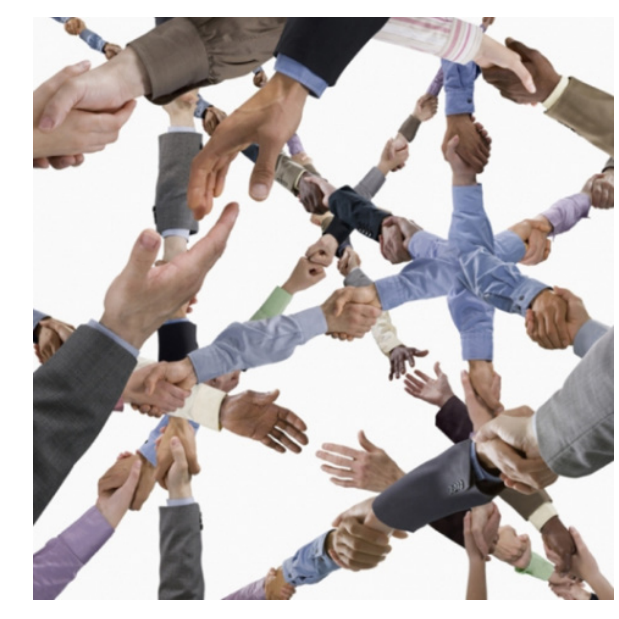

Picture 1. Connecting

The meaning of 'reciprocal dependence, predicament' 
has become the main in the word связь (svyaz') 'connection', which corresponds to the norm of evolution of the semantic paradigm of this word. Since the noun связь (svyaz') - 'connection' has developed its abstract semantics, the gradual process of formation of a compound preposition в связи c (v svyazi s) - 'in connection with' started. Common non-derivative prepositions 'in' and 'with', being structural components of a complex derivative of the preposition в связи с (in connection with) - 'in connection with', fulfill their meaning in its composition, the function of relativity and form the ability of the derivative preposition to participate in bilateral syntactic relations as a connecting word. For example, in the sentence 'He did not come to school in connection with (due to) illness', the preposition в связи с (in connection with) - 'in connection with" enters into a syntactic connection with the verb 'come' and the noun 'ilness', while expressing the cause-effect relationship between them. In the opinion of E. Cherkasova, the formation of a preposition 'in connection with' was the result of grammaticalization of the 'nominal part of descriptive verbal constructions that include existential verbs (быть, находиться, стоять, состоять и т.П. в связи с чем-нибудь - 'to be, to stand, to become', etc. 'in connection with' something) (Cherkasova, 1967: 143) as well as the verbs of knowledge (изучать, анализировать, рассматривать что-либо в связи с чем-либо - 'study', 'analyze', 'consider' anything 'in connection with' something). It is in combination with these semantic groups of verbs that the word 'connection' more or less retains the meaning of the noun. The loss of the subject semantics of this 'nominal part' was associated with the expansion of its compatibility. The components of the structure of the derivative preposition 'in connection with' (the noun 'connection' and simple prepositions 'in' and 'with') determine its ability to denote a certain type of logical relationship. In this case, the semantic meaning of the original noun 'connection' and the non-derivative prepositions 'in' and 'with' which form the prepositional combination в связи с (v svyazi s) - 'in connection with', is not the same. The central semantic and structurally necessary component is the noun 'connection' that forms the semantic core of the derived preposition: the expression of the connectedness of two situations - from the 'right' and from the 'left' of the preposition. The nature of 'connectedness' can be different: it is possible to express cause and effect (Взял отпуск в связи с накопившейся усталостью (vzyal otpusk $v$ svyazi $s$ nakopivsheisya ustalostyu) - 'I took a leave in connection with the accumulated fatigue'), indirectly motivating (Движение транспорта перекрыли в связи с приездом министра (dvizhenie transporta perekryli $v$ svyazi s priezdom ministra - 'The transport movement was blocked in connection with the arrival of the minister') or associative (Гуляя по городу, я встретил своего приятеля.(встретил приятеля в связи с прогулкой (Gulyaya po gorodu, ya vstretil svoego priyatelya (vstretil priyatelya $v$ svyazi s progulkoy) - 'Walking in the city I came across a friend of mine' = 'I met my friend in connection with my roaming in the city').

Simple non-derivative prepositions 'in' and 'with' merely help express this semantics. This three-member structure itself 'in connection with' assumes the grammaticalization of the construction and its functioning as a means of controlling the substantive ablative case, that is, as a preposition. $B$ связи со сложившимся положением была создана авторитетная комиссия. / Отправитель отвечает за все убытки, причиненные в связи с перевозкой указанного груза. Кодекс торгового мореплавания Союза ССР. В зависимости от чего-л., 6 соответствии с чем-л. (во 2 знач.) Некоторые весенние расселения широколиственного леса обладают замечательной способностью менять окраску своих иветков в связи с возрастом. V svyazi so slozhivshimsya polozheniyem byla sozdana avtoritetnaya komissiya. / Otpravitel' otvechayet za vse ubytki, prichinennyye $v$ svyazi s perevozkoy ukazannogo gruza. Kodeks torgovogo moreplavaniya Soyuza SSR. V zavisimosti ot chego-l., v sootvetstvii s chem-l. (vo 2 znach.) Nekotoryye vesenniye rasseleniya shirokolistvennogo lesa obladayut zamechatel'noy sposobnost'yu menyat' okrasku svoikh tsvetkov $v$ svyazi s vozrastom. - 'In connection with (due to) to the situation an authoritative commission has been set up'. / 'The sender is responsible for all losses incurred in connection with the carriage of the said cargo'. (Maritime code of the USSR) 'Depending on something', 'in accordance with' (in second meaning). 'Certain spring settlements of broad-leaved forests have a remarkable ability to change the color of their flowers in connection with (due to) their age'. (Rogozhnikova, 1991: 69-70). 


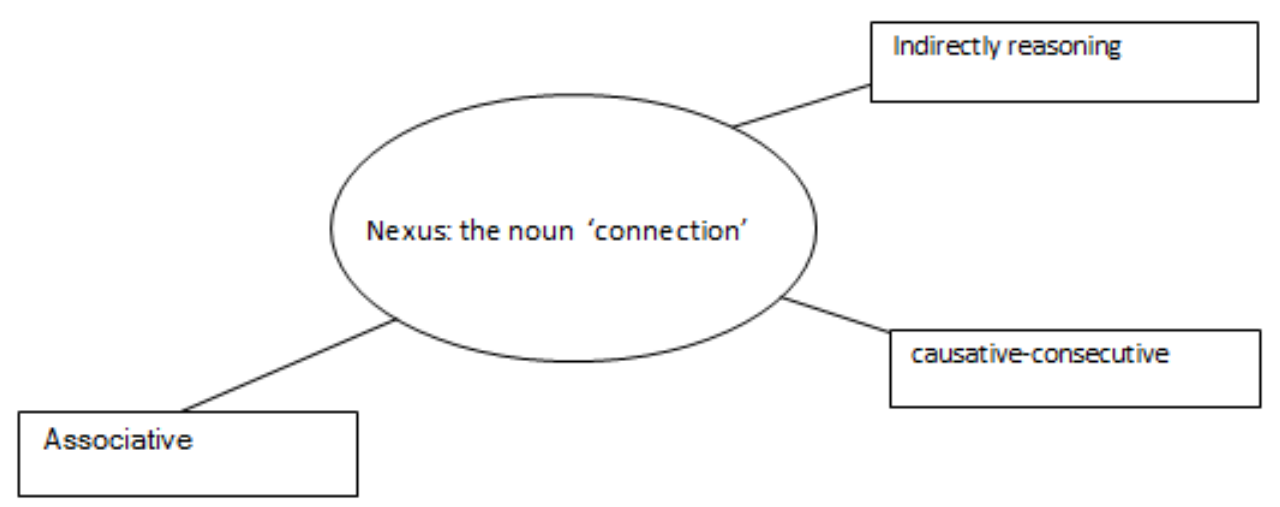

Diagram 1. How the preposition is connected

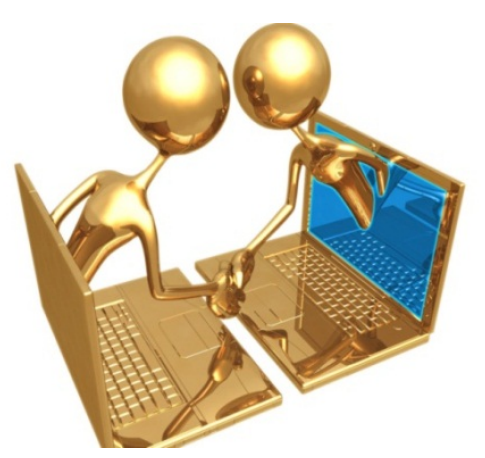

Picture 2. Connection

\section{Materials and Results}

Thus, the study of the semantic features of the combination в связи с (v svyazi s) - 'in connection with', as well as the analysis of dictionary entries allows us to treat this combination as a special functional lexical unit - a derivative preposition. The existence of a derivative preposition 'in connection with' generates questions related to its syntagmatics and the communicative potential of the combinations formed on its basis.

\subsection{Peculiarities of the Use of Preposition in Connection with Anaphoric Pronouns}

It is interesting to consider the use of the preposition в связи c (v svyazi s) - 'in connection with' together with the anaphoric pronouns (возник в связи с ним, отказаться в связи с другим проектом, расстроился в связи с его уходом, отказаться в связи с таким решением (voznik v svyazi s nim, otkazat'sya $\mathrm{v}$ svyazi s drugim proyektom, rasstroilsya $v$ svyazi s yego ukhodom, otkazat'sya v svyazi s takim resheniyem) - 'arose in connection with it', 'refuse in connection with another project', 'was upset in connection with his departure', 'refuse in connection with such a decision'). Anaphoric pronouns are those pronouns that 'contain in their meaning a reference to a given utterance or to the text into which it is included'. Anaphoric pronouns refer either (more often) to the previous place of the text, or (more rarely) to the subsequent (the so-called introductory pronouns). Let us examine the effect of the typological affiliation of the prepositional unit в связи с (v svyazi s) 'in connection with' on its use with anaphoric pronouns. Being a noun preposition and maintaining a close connection with the original noun, связь (svyaz') 'connection', the construction в связи с (v svyazi s) - 'in connection with' is used with various anaphoric pronouns (personal, possessive, relative and indicative)

We have investigated 200 sentences from open sources: articles from Russian newspapers, as well as the authors recorded TV and radio broadcasts, speech samples of native speakers whom the authors address to convey a certain idea with the help of the construction 8 связи с ( $v$ svyazis) - 'in connection with'. The results are presented in the diagram. 


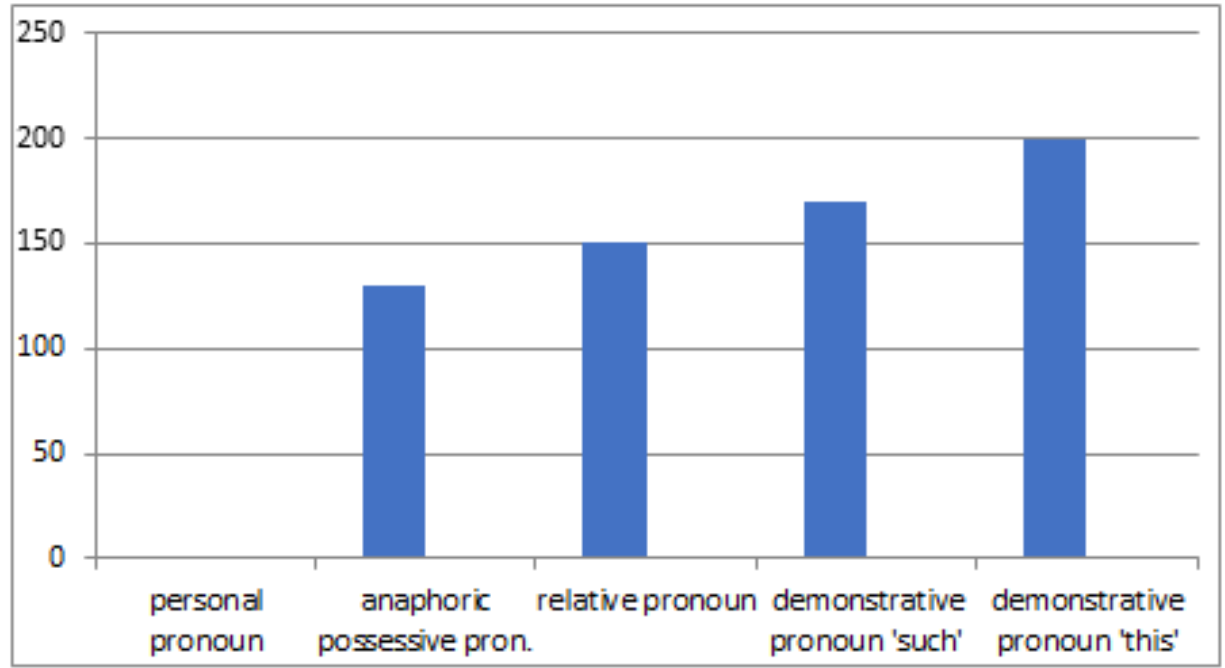

Diagram 2. The number of usage of the preposition 'in connection with' with anaphoric pronouns

Thus, studies of linguistic material showed that for the derivative causal preposition в связи с (v svyazi s) 'in connection with' the combinations with personal pronouns are less common, for example: В результате именно реконструкиия и возникший в связи $c$ ней фантастический проект Эрика Мосса оказались в этом сезоне самой громкой художественной акиией, связанной с именем Гергиева.; Мне было разрешено сформулировать идею фильма и нашу просьбу в связи с ним. (V rezul'tate imenno rekonstruktsiya $i$ voznikshiy $v$ svyazi s ney fantasticheskiy proyekt Erika Mossa okazalis' $v$ etom sezone samoy gromkoy khudozhestvennoy aktsiyey, svyazannoy s imenem Gergiyeva.; Mne bylo razresheno sformulirovat' ideyu fil'ma i nashu pros'bu v svyazi s nim) 'As a result, it was the reconstruction and the fantastic project of Eric Moss, which appeared in connection with it, that this season became the loudest artistic event connected with Gergiev's name'; 'I was allowed to formulate the idea of the film and our request in connection with it'. Constructions of derived preposition в связи с (v svyazi s) 'in connection with' are possible with anaphoric possessive pronouns, for example: В.В. Путин поздравил М. Сингха в связи $c$ его вступлением в должность премьер-министра Республики; Я надеюсь, дорогой мой друг, что горе никогда не коснется вас в связи с ее именем (V.V. Putin pozdravil M. Singkha v svyazi s yego vstupleniyem $v$ dolzhnost' prem'yer-ministra Respubliki; YA nadeyus', dorogoy moy drug, chto gore nikogda ne kosnetsya vas $v$ svyazi s yeye imenem) - 'V. Putin congratulated $\mathrm{M}$. Singh in connection with his taking the office of the Prime Minister of the Republic'; 'I hope, my dear friend, that grief will never touch you in connection with her name'. More common are the combinations of the derivative preposition в связи с (v svyazi s) - 'in connection with' and anaphoric relative pronouns, for example: Аналитики объясняют такую перемену двумя основными причинами - ожесточением конкуренции между British Airways $u$ Lufthansa $u$ широкомасштабным планом британской авиакомпании по оснащению своего авиапарка новыми самолетами, в связи с которым уже объявлен тендер с участием пяти западных авиастроителей на поставку 60 самолетов на сумму \$1 млрд. В 1960-е годы происходит изменение политического климата, в связи с чем смешаются акиенты по отнотению $\kappa$ прошлому и его символам. (Analitiki ob"yasnyayut takuyu peremenu dvumya osnovnymi prichinami ozhestocheniyem konkurentsii mezhdu British Airways $i$ Lufthansa $i$ shirokomasshtabnym planom britanskoy aviakompanii po osnashcheniyu svoyego aviaparka novymi samoletami, $v$ svyazi s kotorym uzhe ob"yavlen tender s uchastiyem pyati zapadnykh aviastroiteley na postavku 60 samoletov na summu $\$ 1$ mlrd. V 1960-ye gody proiskhodit izmeneniye politicheskogo klimata, v svyazi s chem smeshchayutsya aktsenty po otnosheniyu $k$ proshlomu $i$ yego simvolam.) - 'Analysts explain this change with two main reasons - the fierce conflict between British Airways and Lufthansa and the large-scale plan of the British airline to equip its fleet with new aircraft, in connection with which a tender has already been announced with the participation of five Western aircraft builders to supply 60 aircrafts worth $\$ 1$ billion. In the 1960s, the political climate starts changing, and 'in this connection' they are shifting the emphasis on the past and its symbols.

The most frequent are the constructions of the derivative preposition в связи с (v svyazi s) - 'in connection with' and anaphoric demonstrative pronouns ('this, such, such'), for example: Люди в Эстонии делятся на две категории: граждане $и$ неграждане. Неграждане, соответственно, это лица, не имеющие эстонского гражданства, в частности - граждане России и люди без гражданства, то есть граждане СССР. Проблемы, в связи с таким делением возникающие, при 
всей своей серьезности, бывают просто комическими. (Lyudi v Estonii delyatsya na dve kategorii: grazhdane $i$ negrazhdane. Negrazhdane, sootvetstvenno, eto litsa, ne imeyushchiye estonskogo grazhdanstva, v chastnosti grazhdane Rossii $i$ lyudi bez grazhdanstva, to yest' grazhdane SSSR. Problemy, v svyazi s takim deleniyem voznikayushchiye, pri vsey svoyey ser'yeznosti, byvayut prosto komicheskimi.) - 'People in Estonia are divided into two categories: citizens and non-citizens. Non-citizens, respectively, are persons who do not have Estonian citizenship, in particular - Russian citizens and stateless people, that is, citizens of the USSR. Problems arising 'in connection with this', seeming serious, are just comic'.

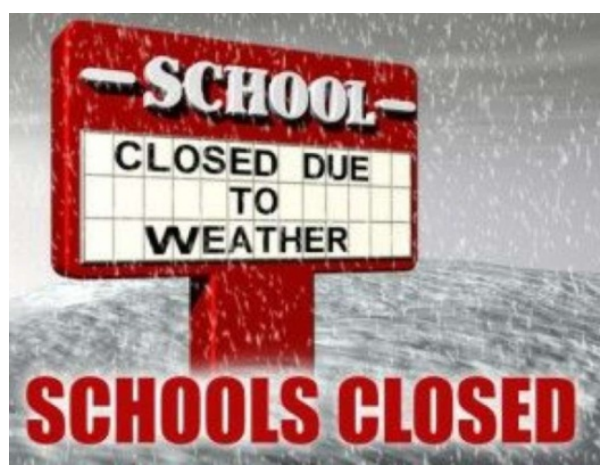

Picture 3. In connection with. In regard of. Due to

Especially actively in the modern speech are used the combinations of the derivative preposition в связи с ( $v$ svyazi s) 'in connection with' and anaphoric demonstrative pronoun 'this', among which two variants of ligamentous constructions are most commonly used: a) a combination 8 связи с этим (v svyazi s etim) - 'in this connection', where 'this' is a substantivized pronoun replacing the antecedent, for example: У Аршавина была травма руки, возможно, в связи с этим и спад в игре, да и слишком много желтых карточек для нападающего (U Arshavina byla travma ruki, vozmozhno, v svyazi s etim i spad v igre, da $i$ slishkom mnogo zheltykh kartochek dlya napadayushchego) - 'Arshavin had a hand injury, perhaps 'in connection with this' one can see a decline in the game, and moreover, he's got far too many yellow cards for the attacker; b) a combination в связи с этим + (v svyazi s etim) 'in connection with this', where the combination of a noun with a mandatory demonstrative adjective - pronoun is the means of substitution of the antecedent, for example: Человек, образ и подобие божье, сотворен из духовной и телесной субстанций. В связи с этим рассуждением Гонорий вводит тему микрокосма или «малого мира» (microcosmus, id est minor mundus); Регистрация печатей в столище узаконена - на прошлой неделе в правовых базах появился Закон г. Москвы от 30.06.04 № 44 «Об учете печатей». Он вступит в силу через 10 дней после официального опубликования. В связи с этой новостью отметим чрезвычайно отрадный факт: регистрация печатей попрежнему останется делом добровольным. (Chelovek, obraz $i$ podobiye bozh'ye, sotvoren iz dukhovnoy i telesnoy substantsiy. $V$ svyazi $s$ etim rassuzhdeniyem Gonoriy vvodit temu mikrokosma ili «malogo mira» (microcosmus, id est minor mundus); Registratsiya pechatey $v$ stolitse uzakonena -na proshloy nedele $v$ pravovykh bazakh poyavilsya Zakon $g$. Moskvy ot 30.06.04 № 44 «Ob uchete pechatey». On vstupit $v$ silu cherez 10 dney posle ofitsial'nogo opublikovaniya. $V$ svyazi s etoy novost'yu otmetim chrezvychayno otradnyy fakt: registratsiya pechatey poprezhnemu ostanetsya delom dobrovol'nym.) 'A person, an image and the likeness of God, is created from spiritual and physical substances. 'In connection with this' reasoning, Honorius introduces the theme of the microcosm or 'small world' (microcosmus, id est minor mundus); 'Registration of seals in the capital is legalized last week in the legal sources there appeared the Law of Moscow of 30.06.04 № 44 'On the seals'. It will come into force 10 days after its official publication. 'In connection with this' news, we note an extremely encouraging fact: the registration of seals will still be voluntary'. These prepositional-pronominal combinations function in parallel and in certain syntactic conditions compete with each other. In addition, the prepositional-case construction в связи с этим ( $v$ svyazi s etim) - 'in this connection' is in the relations of speech conflict with the substantive-qualitative construction в этой связи (v etoy svyazi) - 'in this regard'.

\subsection{The Usage of Prepositional Constructions 'in Connection with', 'in Connection with this' Plus the Noun in the Ablative Case' in Different Syntactic Positions}

The analysis of linguistic material has shown that the prepositional constructions в связи с этим (v svyazi s etim) - 'in connection with this' and в связи с этим (этой) $v$ svyazi s etim (etoy) - 'in connection with this with this plus the noun in the ablative case' form the conditioning relationships between two situations.

Table 1. Conditioning relationship between the situations

\begin{tabular}{ll}
\hline A & by units of a simple sentence, \\
\hline B & by units of a complex sentence, \\
\hline C & units of the text
\end{tabular}

Let us consider all cases.

A) In a simple sentence, the prepositional constructions в связи с этим (v svyazi s etim) - 'in connection with this' and в связи с этим (этой) v svyazi s etim (etoy) - in connection with this plus the noun in the ablative case' form the conditioning relationships between two situations expressed by words with propositional semantics, for example: Москвич почувствовал некоторое головокружение и в связи с этим головокружением как бы подбоченился в кресле); Он постоянно встречался с сотрудниками фирмы и мне дважды давал задания в 
связи с этим. (Moskvich pochuvstvoval nekotoroye golovokruzheniye $i$ v svyazi s etim golovokruzheniyem kak by podbochenilsya v kresle); On postoyanno vstrechalsya s sotrudnikami firmy i mne dvazhdy daval zadaniya $v$ svyazi $s$ etim.) - 'The Muscovite felt some vertigo and, in connection with this dizziness he put his arms akimbo in the armchair'; 'He constantly met with the company's employees and twice gave me assignments "in connection with this'. In these examples, the predicament situation on the 'left' of the prepositions is expressed by the 'Muscovite felt vertigo' and 'he met with the company's employees'. The antecedents are replaced by 'this vertigo' and substantivatum 'by this' on the 'right' from the preposition, but they only duplicate what has already been said and, thus, in conjunction with the preposition, perform the structural function of the logical bundle. Predicament situations are expressed by the words 'he put his arms akimbo in the armchair' and 'gave assignments' and are placed 'on the right' of the ligamentous prepositional combinations в связи с этим головокружением и в связи с этим (v svyazi s etim golovokruzheniyem i v svyazi s etim) - 'in connection with this 'vertigo' and 'in regard with this'.

B) In a complex sentence the combination в связи $c$ этим (v svyazi s etim) - 'in this connection' and в связи с этим (этой) v svyazi s etim (etoy) - 'in connection with this plus the noun in the ablative case' serve the ties between predicative bases, for example: $A$ я смотрюсь, $u$ у меня в связи с этой привычкой назрел вопрос... Препарать на основе ромашки ослабляют аллергические реакции, в связи с этим возможно их применение при бронхиальной астме. ('A ya smotryus', $i$ $u$ menya $v$ svyazi $s$ etoy privychkoy nazrel vopros... Preparaty na osnove romashki oslablyayut allergicheskiye reaktsii, $v$ svyazi s etim vozmozhno ikh primeneniye pri bronkhial'noy astme.) - 'And I look, and 'in connection with this' habit a question arose' ... 'The medications based on chamomile weaken allergic reactions, and 'in connection with this' it is possible to use it against bronchial asthma'. In these examples the description 'this habit' and the substantivat 'this' replace the situation-reason, expressed by the grammatical basis (' $\mathrm{I}$ look') and the situation-cause ('medications weaken'), respectively. With the help of a preposition, the anaphoric components associate the predicament situations with conditioned ones, expressed by 'a question arose' (an indirect consequence) and 'the use (direct consequence) is possible'.

C) Within the framework of the text, the prepositional constructions в связи с этим (v svyazi s etim) 'in this connection' and в связи с этим (этой) $v$ svyazi s etim (etoy) - 'in connection with this plus the noun in the ablative case' act as a bundle between independent sentences or complex syntactic integers that verbalize the situations that are in predicament relationship, for example: В прошлом году сезон продаж загородной недвижимости начался только летом. В связи с этим опозданием, а также ожиданием значительной части покупателей падения цеен в наиболее дорогих секторах рынка, объемы продаж в данном сегменте снижались; Фермерские хозяйства кардинально отличаются от ЛПХ других типов, и в основных статистических справочниках Госкомстата России они рассматриваются отдельно от хозяйств населения, то есть от собственно личных подсобных хозяйств. $B$ связи с этим они специально не обсуждаются в настоящей статье. (V proshlom godu sezon prodazh zagorodnoy nedvizhimosti nachalsya tol'ko letom. V svyazi $s$ etim opozdaniyem, a takzhe ozhidaniyem znachitel'noy chasti pokupateley padeniya tsen $v$ naiboleye dorogikh sektorakh rynka, ob"yemy prodazh $v$ dannom segmente snizhalis'; Fermerskiye khozyaystva kardinal'no otlichayutsya ot LPKH drugikh tipov, $i v$ osnovnykh statisticheskikh spravochnikakh Goskomstata Rossii oni rassmatrivayutsya otdel'no ot khozyaystv naseleniya, to yest' ot sobstvenno lichnykh podsobnykh khozyaystv. V svyazi $s$ etim oni spetsial'no ne obsuzhdayutsya $v$ nastoyashchey stat'ye) - 'Last year, the suburban real estate sales season began only in summer'. 'In connection with this delay, as well as the expectation by a significant part of buyers of price falling in the most expensive sectors of the market, sales in this segment declined'; 'Farmer households are fundamentally different from other types of private farm holding, and in the main statistical reference books of the State Statistics Committee of Russia they are considered separately from the households of the population, that is, from the personal subsidiary plots'. 'In this regard they are not specifically discussed in this article'. Thus, the anaphoric indicative components included in the composition of the proposal constructions 6 связи с этим ( $v$ svyazi s etim) - 'in this connection' and 6 связи с этим (этой) v svyazi s etim (etoy) - 'in connection with this plus the noun in the ablative case' replace a certain situation 'on the left', expressed by a combination of words (most often by a verbal group) by a sentence or a complex syntactic unit, and indicate the reason/ incentive for the occurrence of the situation 'on the right', expressed in similar ways.

Having discovered the active use of the derivative preposition в связи с ( $v$ svyazi s) - 'in connection with' and the anaphoric demonstrative pronoun 'this', and having established the parallel functioning of the prepositional-case combination в связи с этим (этой) $v$ svyazi $s$ etim (etoy) - 'in connection with this' and prepositional-pronominal construction 'in connection with this plus the noun in the ablative case' in different syntactic conditions, let us consider the dynamics of the use of these combinations in speech.

In modern speech, combined with an anaphoric substantivized pronoun 'this', the derived preposition 6 связи с (v svyazi s) - 'in connection with' forms a stable prepositional-case combination в связи с этим (v svyazi s 
etim) -'in this connection', actively used in modern speech as a means of logical connection between the components of the sentence and the text and formulating different relationships of predicament between the two situations. For example, in the text Только за счет государственной поддержки могут выжить культурные программы на телевидении», (Tol'ko za schet gosudarstvennoy podderzhki mogut vyzhit' kul'turnyye programmy na televidenii) - сказал министр. В связи с этим он высказался против приватизации государственных компаний ( $V$ svyazi $s$ etim on vyskazalsya protiv privatizatsii gosudarstvennykh kompaniy - 'Only thanks to the state support can cultural programs survive on television', the minister said. 'In this regard he spoke out against the privatization of state-owned companies'. The first situation which is noted by the allocated pronoun (confidence in the need for state support) determines the second (opposition to privatization) as an immediate cause, and the combination в связи с этим (v svyazi s etim) - 'in this connection' therefore expresses cause-effect relationships. But in the text Выбрав между профессией и семьей в пользу семьи, понимая, что «в одной руке два арбуза не унесешь», я знала, что рядом со мнойвеликий музыкант. Что может в связи с этим значить средняя карьера артистки? первая ситуация (муж - великий музыкант) Vybrav mezhdu professiyey $i$ sem'yey v pol'zu sem'i, ponimaya, chto «v odnoy ruke dva arbuza ne unesesh'», ya znala, chto ryadom so mnoy velikiy muzykant. Chto mozhet $v$ svyazi s etim znachit' srednyaya kar'yera artistki? pervaya situatsiya (muzh velikiy muzykant) - 'Choosing between the profession and the family in favor of the family', realizing that 'in one hand you cannot take two watermelons,' I knew that next to me there was a great musician. What, in this connection, will the average career of an actress mean? The first situation (her husband is a great musician) determines the second (minor importance of his wife's career) in a much more indirect way, mainly as an excuse. Thus, here the combination в связи с этим (v svyazi s etim) - 'in this connection' formalizes the indirect relations of predicament between the two situations. So, the expression 'in this connection' itself means only the extremely general relations of conditionality, the more specific character of these relations is formed in the context. The prepositional-pronominal combination в связи с этим (v svyazi s etim) - 'in this connection' is not distinguished by any of the dictionaries of the modern Russian language as a lexicalized unit, although it possesses certain signs of stability. This can be explained by the fact that this combination is deprived of phraseology: its meaning is derived from the meaning of the preposition 'in connection with' and the substantivized pronoun this/that: that is why it fits the preposition model: в связи с (чем / с чем-либо) $v$ svyazi $s$ (chem / s chem-libo) in connection with (something) (see. Ushakov Dictionary, 2000, V. 4: 108; Small Academic Dictionary 1999, Vol. 4: 59;
Rogozhnikova, 1991: 69-70). The construction 'In this connection' performs the functions of a logical link in the structure of both a simple and a complex sentence, but mainly between the sentences of the text, for example:

- a simple sentence: Рассмотрим теперь механизм зарождения и развития звезд, а также в связи с этим классификацию звезд и методы их наблюдения; (Rassmotrim teper' mekhanizm zarozhdeniya i razvitiya zvezd, a takzhe v svyazi s etim klassifikatsiyu zvezd i metody ikh nablyudeniya); 'Let us now consider the mechanism of nucleation and development of stars, and, in this connection, the classification of stars and methods of their observation';

- a complex sentence: - сложное предложение: После осуждения в Москве в конце 1553 года распространившейся ереси на Соловки был сослан бывший Троицкий игумен Артемий, и в связи с этим игумену Филиппу 24 января 1554 года была направлена Соборная грамота (slozhnoye predlozheniye: Posle osuzhdeniya v Moskve v kontse 1553 goda rasprostranivsheysya yeresi na Solovki byl soslan byvshiy Troitskiy igumen Artemiy, i v svyazi s etim igumenu Filippu 24 yanvarya 1554 goda byla napravlena Sobornaya gramota ) - After condemnation of the spread of heresy in Moscow at the end of 1553, the former Holy Trinity Hegumen Artemy was exiled to Solovki, and in this connection, on January 24, 1554, the Hegumen Philip was sent a Covenant of letters;

- at the junction of sentences in the text: - Как справедливо подчеркивал президент РФ В.В. Путин, борьба с терроризмом требует активных, упреждающих действий. В связи с этим есть необходимость остановиться на трех аспектах борьбы с терроризмом. (Kak spravedlivo podcherkival prezident RF V.V. Putin, bor'ba $s$ terrorizmom trebuyet aktivnykh, uprezhdayushchikh deystviy. V svyazi s etim yest' neobkhodimost' ostanovit'sya na trekh aspektakh bor'by $\mathrm{s}$ terrorizmom.) - 'As rightly stressed by the President of the Russian Federation V.V. Putin, the fight against terrorism requires active, proactive actions. "In this connection, there is a need to dwell on three aspects of the fight against terrorism. In the syntactic structures of a sentence or text, the construction в связи с этим' (v svyazi s etim) - in this connection' combines two components expressing a propositional meaning.

The analysis of factual material showed that the use of the prepositional combination в связи с этим' (v svyazi s etim) - 'in this connection' in a simple sentence (165 uses)

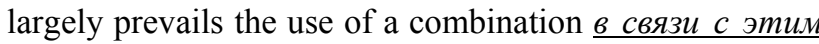
(эmoü) v svyazi s etim (etoy) - 'in connection with this plus the noun in the ablative case' ( 5 uses). In the structure of a complex sentence, practically the same number of uses of the prepositional-pronominal combination в связи с этим' 
(v svyazi s etim) 'in connection with this' are found, as in the simple sentence (161 uses). In this case, the speech activity of the combination в связи с этим' ( $v$ svyazi s etim) - 'in this connection' also considerably exceeds the activity of the prepositional-case combination в связи с этим' ( $v$ svyazi s etim) - 'in this connection' (12 uses). Most actively the construction в связи с этим' (v svyazi s etim) - 'in this connection' is used on the border of two sentences in the text (2,023 uses).

Table 2. The usage of prepositional combinations in different syntactic combinations

\begin{tabular}{|l|c|c|c|}
\hline & $\begin{array}{c}\text { Simple } \\
\text { sentence }\end{array}$ & $\begin{array}{c}\text { Complex } \\
\text { sentence }\end{array}$ & $\begin{array}{c}\text { At the boundary of } \\
\text { sentences in the } \\
\text { text }\end{array}$ \\
\hline $\begin{array}{l}\text { Prepositional 'in } \\
\text { combination } \\
\text { this connection' }\end{array}$ & 165 & 161 & 2023 \\
\hline $\begin{array}{l}\text { 'in connection with } \\
\text { this' plus the noun } \\
\text { in the ablative case' }\end{array}$ & 5 & 12 & -- \\
\hline
\end{tabular}

The analysis of the dynamics of the use of the prepositional-pronominal combination в связи с этим (v svyazi s etim) - 'in this connection', in abstraction from the type of syntactic construction, confirms the steady increase of the speech activity of construction в связи с этим (v svyazi s etim) 'in this connection'. The analysis showed that in all types of syntactic constructions, the use of the prepositional-pronominal combination в связи с этим (v svyazi s etim) - 'in this connection' as a ligamentous agent largely prevails the use of the combination в связи с этим ( $v$ svyazi s etim) - 'in connection with this' plus the noun in the ablative case.

The preferences of the laconic two-component expression в связи с этим (v svyazi s etim) - 'in this connection' can be explained by the ability of this anaphoric pronoun this THIS to replace, without any semantic limitations, the preceding segment of the sentence or text, which denotes to a certain situation related to the subsequent situation, and these relations are conditioned. This ability of the prepositional combination в связи с этим (v svyazi s etim) - 'in this connection' greatly facilitates the communicative task of the speaker.

The Analysis of the statistics of the use of constructions в этой связи (v etoy svyazi) - 'in this regard' and в связи с этим ( $v$ svyazi s etim) - 'in connection with this plus the noun in the ablative case' testifies to the emerging trend of equalizing the number of uses of the two competitors. In addition, currently people are more likely to use the option 'in this regard', which is particularly vividly demonstrated by the language of the media and the sphere of public communication in general. At the same time, the use of the construction $в$ этой связи (v etoy svyazi) - 'in this regard' in the media now continues to grow, which is shown by our own observations of oral speech on television. Here are some typical examples: Сельские поселения $u$ муниципальные районы практически полностью зависят от помощи выщестоящих бюджетов, а их собственные доходы зачастую не превылают 30\%... В этой связи сельские администрации вынуждень передавать на районный уровень часть функций; Еще одна тема - «мобильность студентов»: возможности учиться не только в родном ВУЗе, но и стажироваться в других районах страны мешает отсутствие жилья. Вопрос: где жить? И в этой связи нам нужно побольше уделять внимания строительству общежитий, конечно; Лукойл, Роснефть, Сургутнефтегаз уже сразу снизили эти цены отпускные с НЗП, а некоторые коллеги объявили о своем решении по снижению цен в ходе совещания: это ТНКВП и Газпромнефть. В этой связи у меня вопрос: как наши решения на совещчании отразились на рынке. Что-то произошло реально на рынке или нет. Снижение реальное состоялось, или этого мы пока не видим; Политика раскачивается, в этой связи хотел бы пожелать всем всех благ в новом году. Sel'skiye poseleniya i munitsipal'nyye rayony prakticheski polnost'yu zavisyat ot pomoshchi vyshestoyashchikh byudzhetov, a ikh sobstvennyye dokhody zachastuyu ne prevyshayut 30\%... V etoy svyazi sel'skiye administratsii vynuzhdeny peredavat' na rayonnyy uroven' chast' funktsiy; - Yeshche odna tema - «mobil'nost' studentov»: vozmozhnosti uchit'sya ne tol'ko $v$ rodnom VUZe, no $i$ stazhirovat'sya $v$ drugikh rayonakh strany meshayet otsutstviye zhil'ya. Vopros: gde zhit'? I v etoy svyazi nam nuzhno pobol'she udelyat' vnimaniya stroitel'stvu obshchezhitiy, konechno; Lukoyl, Rosneft', Surgutneftegaz uzhe srazu snizili eti tseny otpusknyye $s$ NZP, a nekotoryye kollegi ob"yavili o svoyem reshenii po snizheniyu tsen $v$ khode soveshchaniya: eto TNKVP $i$ Gazpromneft'. V etoy svyazi u menya vopros: kak nashi resheniya na soveshchanii otrazilis' na rynke. Chto-to proizoshlo real'no na rynke ili net. Snizheniye real'noye sostoyalos', ili etogo my poka ne vidim; Politika raskachivayetsya, $v$ etoy svyazi khotel by pozhelat' vsem vsekh blag $v$ novom godu.

'Rural settlements and municipal districts almost completely depend on the help of higher budgets, and their own incomes often do not exceed $30 \%$... In this regard, rural administrations are forced to transfer some functions to the district level'; - Another topic is the 'mobility of students': the opportunity to learn not only in the home university, but also to be trained in other parts of the country is hampered by the lack of housing. The question is: where to live? And in this regard, we need to pay more attention to the construction of hostels, of course'; 'Lukoil, Rosneft, Surgutneftegaz immediately lowered retail prices, and some colleagues announced their decision to reduce prices in the course of the meeting. Iin this regard, I have a question: how did our decisions at the meeting affect the market? Has something really happened on the market or not? Has a real decline taken place, or we haven't seen it yet?; 'Politics is swinging, and in this regard, I would like to wish all the best in the new year'. The data obtained by 
us testify that at present the expression в этой связи (v etoy svyazi) - 'in this regard' has become a marker in the discourse of well-educated people, so that all the prerequisites have been created for considering the construction $в$ этой связи (v etoy svyazi) - 'in this regard' as a special lexical unit with a developed idiomatic meaning, and performing the function of a logical bundle, expressing the different degree of conditionality of two situations. It is this interpretation of this construction that allows native speakers to actively use it in speech. It is to be assumed that the further use of the construction $в$ этой связи ( $v$ etoy svyazi) - 'in this regard' will only increase. This is proved by its active use in the discourse of the media, which has a huge impact on the public consciousness and speech of the speakers.

\section{Conclusions}

Based on the material discussed, a number of conclusions can be done. The analysis of the text paradigm of the preposition в связи с (v svyazi s) - in connection with showed that this unit is actively used in constructions with an anaphoric pronoun эmom this, with its greatest use in the speech of the prepositional-pronominal construction в связи с этим (v svyazi s etim) - 'in this connection with this' and the smallest use of the prepositional expression $b$ связи с этим (этой) (v svyazi s etim) - 'in connection with this' plus the noun in the ablative case.

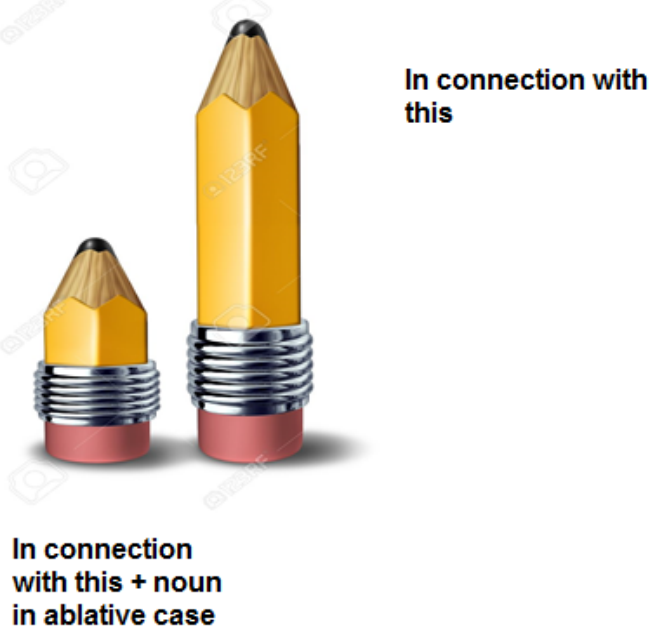

Picture 4. Differences of uses

The choice of the anaphoric demonstrative pronoun this in the prepositional unit в связи $c$ (v svyazi $\mathrm{s}$ ) - 'in connection with' can be the explained by the fact that it is attributed to the causal prepositions and by the semantic relations expressed by the derived preposition в связи с (v svyazi $s$ ) - 'in connection with' (the most general conditioning relations between the two situations), as well as by the interaction of the preposition with the predicative antecedent represented by the event vocabulary and practically not affecting the actant word with the derived preposition. The prepositional combinations в связи с этим (этой) (v svyazi s etim) - 'in connection with this' (that), в связи с этим (v svyazi $s$ etim) - 'in this connection' and the nominal correlate $в$ этой связи (v еtoy svyazi) - 'in this regard', formed on the basis of a composite denominative preposition в связи с (v svyazi s) 'in connection with' function in the modern speech in a parallel way and compete with each other under certain syntactic conditions. In a simple and complex sentence, as well as on the boundary of the units of a text (sentences), the prepositional-pronominal combination в связи с этим (v svyazi s etim) - 'in this connection' and the substantive-definitive expression в этой связи (v etoy svyazi) - 'in this regard' is predominantly used. The prepositional combination в связи с этим (этой) (v svyazi s etim) - 'in connection with this' (that) plus the noun in the ablative case rarely comes into conflict with the above constructions.

The parallel functioning of prepositional and noun clause as structural and semantic equivalents affects both competing options. On the one hand, despite the rather stable status in the system of the auxiliary parts of speech, the preposition в связи с (v svyazi s) - 'in this connection' reveals reflections of its nominal nature in this speech conflict. On the other hand, the functional and semantic analogy with the preposition facilitates the formation of stable substantive-determinative constructions (for example, в этой связи (v etoy svyazi), в прямой связи с (v pryamoy svyazi) - 'in this regard', 'in direct connection with', 'in indissoluble connection with'), which in the process of grammaticalization move into the field of auxiliary instruments of the Russian language.

Within the framework of the phenomenon of the speech conflict, we have explored the semantic features and syntactic conditions for the functioning of functional and semantic analogues - prepositional and case combinations в связи с этим (v svyazi s etim) - 'in this connection', в связи с этим (этой) (v svyazi s etim (etoy)) - 'in connection with' plus the noun in the ablative case, and the pronominal construction 'in this regard'. The choice of linguistic material was due to the demand for these constructions in modern communication. The conducted research allowed us to draw the following conclusions.

1. The derivative preposition в связи с (v svyazi s) - 'in connection with' genetically goes back to the noun связь (svyaz') - 'connection', the lexical meaning of which formed the ability of these prepositions to express logical relationships of conditionality. In modern speech, the derivative preposition в связи с ( $v$ svyazi s) - 'in connection with' is extremely common, due to its 'wide' semantics and almost unlimited use.

2. On the basis of the denominative preposition в связи c (v svyazi s) - 'in connection', the prepositional and case combinations with the anaphoric pronoun 
связи с этим (v svyazi s etim) - 'in this connection', в связи с этим (этой) (v svyazi s etim (etoy)) - 'in connection with this' (plus the noun in the ablative case) were formed. The functional-semantic analogues of these prepositional-case combinations are (respectively) substantive-attributive collocations with anaphoric pronoun в этой связи (v etoy svyazi) 'in this regard'.

Progressions в связи с этим (v svyazi s etim) - 'in connection with this', в связи с этим (этой) (v svyazi s etim (etoy)) - 'in connection with this' (plus the noun in the ablative case), в этой связи (v etoy svyazi) - 'in this regard' form a kind of text paradigm. The invariant structural feature of the paradigmatic series is the basic units в связи с / связь (v svyazi s) /svyaz' -'in connection with' / 'connection', as for the invariant semantic sign it is the expression of causality relation between the 'left' and 'right' situations, as well as the function of the logical link in the sentence and text.

3. Along with the prepositional-case combination в связи с этим (v svyazi s etim) - 'in connection with this', в связи с этим (этой) (v svyazi s etim (etoy)) 'in connection with this' plus the noun in the ablative case, in modern speech its functional and semantic equivalent в этой связи ( $v$ etoy svyazi) - 'in this regard' is actively used. In modern speech, this substantive-attributive phrase is used to express the relationships between the conditionality of two situations. The phrase в этой связи (v etoy svyazi) 'in this regard'is characterized by illogicality, because it does not have such a referent in the context on the 'left', which could be indicated by the word связь (svyaz') - 'connection'. Thus, the construction 'in this connection' cannot be understood based on the value of its constituent units, and is a phraseologized unit. Despite the logical 'irregularity' of the construction в этой связи (v etoy svyazi) - 'in this regard', native speakers often use it in their speech as a kind of formula for transition from one thought to another and even prefer it to a logically 'correct' construction связи с этим (v svyazi s etim) - 'in this connection'. This is evidenced by the obtained statistical data.

The widespread use of the word combination в этой связи (v etoy svyazi) - 'in this regard', both in the discourse of the media and in scientific discourse, in our opinion, evidences not only its reproducibility as an integral lexical unit, but also allows us to raise the question of reflecting it in dictionaries as a normative lexicalized construction of a liaison. The construction в этой связи (v etoy svyazi) - 'in this regard', by virtue of its semantic 'lameness', is evaluated by us as a secondary formation on the basis of the prepositional-pronominal combination в связи с этим (v svyazi s etim) - 'in this connection', its peculiar transform showing an ability of penetration of the derivative denominative preposition.

It can be stated that in the discourse of the media, bookish ligaments in the form of derivatives of denominative prepositions are in demand, which may be due to the tendency noted by the researchers towards the stylistic averaging of the media language. As the analysis of the use of this construction has shown, it is mainly used in the pre-position directly at the junction of sentences in the text, at the meantime the use of the substantive-attributive combination 'in this connection', which has a broader lexical meaning, is more common.

4. Inside the paradigm в связи с этим (v svyazi s etim) 'in this connection', в связи с этим (этой) (v svyazi s etim (etoy)) - 'in connection with this' plus the noun in the ablative case, and в этой связи (v etoy svyazi) - 'in this regard' the conflict of variants of the logical bundle is characterized by the following regularities. In a simple sentence the prepositional-pronominal combination в связи с этим (v svyazi s etim) - 'in connection with this' is more often used. The substantive-qualitative construction в этой связи (v etoy svyazi) - 'in this regard' is less often seen, and finally, the least used is the prepositional-case combination в связи с этим (v svyazi s etim) - 'in this connection' plus the noun in the ablative case.

In the complex sentence, as a link between the predicative parts, the preferential use of the prepositional-case combination в связи с этим (v svyazi s etim) - 'in this connection' was also revealed. Expressions в этой связи(v etoy svyazi) - 'in this regard' and в связи с этим (этой) (v svyazi s etim (etoy)) - 'in connection with this' plus the noun in the ablative case in these situations are used less often. However, the use of the combination в этой связи (v etoy svyazi) - 'in this regard' quantitatively still exceeds the use of the combination в связи с этим (этой) (v svyazi s etim (etoy)) - 'in connection with this' plus the noun in the ablative case. At the border of two sentences (or complex syntactic integers) in the text more uses of the normative prepositional-pronominal combination в связи с этим ( $v$ svyazi s etim) - 'in this connection' are registered, however, in recent times in the Russian speech there has been a remarkable increase in the use of the 'wrong' nominative expression в этой связи (v etoy svyazi) - 'in this regard'. The prepositional-case combination в связи с этим (этой) (v svyazi s etim (etoy)) - 'in connection with this' plus the noun in the ablative case also occurs in the position between the sentences of the text, but these uses are so few that it is difficult to talk about its full conflict with the constructions в связи с этим (v svyazi s etim) - 'in 
this connection' and в этой связи (v etoy svyazi) - 'in this regard'.

5. Thus, in all syntactic conditions (within the framework of a simple or a complex sentence, as well as within the text), to express causational relations including cause-and-effect relations the prepositional-case combination в связи с этим (v svyazi s etim) - 'in connection with this' is most often used, which is explained by the breadth of its semantics and simplicity, since this substance easily allows you to 'curtail' any context 'on the left'. Noticeably less frequently in modern speech under different syntactic conditions (simple and complex sentences, as well as at the sentence boundary or in the text), the prepositional case nouns in the ablative are used. It is probable that their use can cause certain difficulties: it is necessary to select the noun-actant, which 'replaces' the previous part of the statement (context 'on the left'). It has been discovered that nouns with event-procedural semantics are used most often (for example: в связи с этим эпизодом (v svyazi s etim epizodom), в связи с этой ситуацией (v svyazi s situaciey) - 'in connection with this episode', 'in connection with this situation'), nouns denoting the speech act and its result (for example: в связи с этим заявлением (v svyazi $\mathrm{s}$ etim zayavleniem), в связи с этой публикацией (v svyazi s publicaciey) - 'in connection with this statement', 'in connection with this publication'); nouns that refer to a mental or psychological state (for example: в связи с этой привычкой(v svyazi s etoy pivychkoy), в связи с этим наблюдением (v svyazi s etim nabludeniem) - 'in connection with this habit', 'in connection with this observation').

6. Explicit competitors in modern speech are synonymous constructions в связи с этим (v svyazi s etim) - 'in connection with this' and в этой связи (v etoy svyazi) - 'in this regard', characterized by the stability of the structure and regular reproducibility. Both constructions carry the functions of a logical link expressing different degree of conditionality of two situations, and both pre-emptively occupy a position at the junction of the two sentences within the text, both can be interchangeable in any context. The active use of these ligament constructions shows that they are in demand by speakers.

The statistical discovered revealed by us while analyzing the linguistic material, as well as observation of public speech in the media, allow us to conclude that, despite the active functioning of the normative prepositional-pronominal combination «in this connection», and the "incorrectness" of the substantive-attributive combination «in this regard», today there is a tendency for speakers to prefer the second option. With a reasonable certainty, it can be assumed that in the future, the substantive-attributive combination $в$ этой связи (v etoy svyazi) - 'in this regard' will win.

It should be emphasized that further study of text paradigms formed on the basis of derivative prepositions / prepositional equivalents, and historically producing nouns seems to be important theoretically, methodologically and in practice. Such kind of research will make it possible to understand more deeply the specifics of a denominative preposition that has all the features of an auxiliary parts of speech and at the same time through syntagmatic and paradigmatic links in the text revealing its "nominal" nature; to trace the objective laws of formation of synonymous stable constructions of a ligature that enter into speech conflict; to reveal the actual tendencies in the development of the vocabulary and grammar of the modern Russian language; to improve the reflection of compound lexical units in dictionaries and reference books. In the future, they can be expanded through such structures as 6 прямой связи с...(v pryamoy svyazi $s), \quad 6$ непосредственной связи с (v neposredstvennoy svyazi s) - 'in direct connection with' ..., 'in direct correlation with' ... etc. In addition, it is of interest to study the functioning of prepositional and nominal combinations in the texts of different styles with statistical calculations. The revealed criteria for comparing ligament constructions can also serve as a basis for comparing such prepositional-case combinations and their speech equivalents.

From the point of view of punctuation, the construction 'in connection' also puts a number of questions, in particular: whether it is separated by a comma. Separation of such a construction is not always appropriate, and sometimes is even erroneous. When using 'in connection' ... in the meaning 'because' at the beginning of the sentence, the comma should be put after the associated word: 'In connection with the shortage in orders, the number of employees has significantly decreased'; 'In connection with the fact that you are always late for work, this month you will be fined'. In addition, the construction 'in connection with ...' is separated if the construction is in the middle of the sentence, clarifies its content and stands out intonationally: Мужчине, в связи с неопрятным внешним видом, было отказано в посещении нашего заведения. В случае расположения конструкиии «в связи с...» в конце предложения (причем в значении «потому что») запятая не используется: Его уволили в связи с категорическим отказом выполнять свою работу. Однако это не относится $\kappa$ сложноподчиненным предложениям: Я заплатил штрар в связи с тем, что судья наложил на меня санкиии. Muzhchine, v svyazi s nеopryatnym vneshnim vidom, bylo otkazano $v$ poseshchenii nashego zavedeniya. $V$ sluchaye raspolozheniya konstruktsii «v svyazi s...»v kontse predlozheniya (prichem v znachenii «potomu chto») zapyataya ne ispol'zuyetsya: Yego uvolili $v$ svyazi s kategoricheskim otkazom vypolnyat' svoyu rabotu. Odnako eto ne otnositsya $k$ slozhnopodchinennym predlozheniyam: 
YA zaplatil shtraf $v$ svyazi s tem, chto sud'ya nalozhil na menya sanktsii. 'The man, in connection with the slovenly appearance, was denied a visit to our institution'. In the case of the being of the structure 'in connection with ... at the end of the sentence (and in the meaning 'because') the comma is not used: 'He was fired in connection with a categorical refusal to do his work'. However, this does not apply to compound sentences: 'I paid a fine in connection with the fact that the judge imposed sanctions on me'. Meanwhile, controversial options for placing punctuation marks are also possible. In this case, the final decision on punctuation is taken by the author of the text.

Thus, we have to note that prepositions, in particular the derivatives, are an insufficiently studied field in the modern philology. This is due to the fact that the relationship between prepositions and case forms is not fully defined in the science. Disagreements of researchers can be traced in the understanding of lexical and grammatical meaning of the preposition.

In addition, consideration of derivative prepositions does not always take into account the features associated with the extremely complex, multidimensional semantic system, formed by this part of speech.

It should also be noted that up to now not all derivative prepositions and their analogues have been fully recorded. When considering the classification of derivative prepositions, taking as a basis any criterion (origin, structure, presence or absence of meaning in the preposition) the preposition is systematized as a part of speech. However, there is still no clear division of prepositions within its class and in subclasses, which is explained by the heterogeneity of the words included in the class of prepositions and the continuing process of their formation.

\section{Acknowledgement}

The research is implemented within the framework of the RUDN University participation in the Russia-wide 5-100 project.

\section{REFERENCES}

[1] Andreevskaya, V. 2007. Section X. Functional units of the Russian language. Proceedings of the III International Congress of Russian Language Researchers "Russian Language: Historic Fates and Modernity". Moscow: Moscow State University: 264. URL: http://www.philol.msu.ru

[2] Bondarenko, V. 1961. Prepositions in the Modern Russian Language. Moscow: Uchpedgiz,

[3] Boriaeva, L. 2010. "On the Characteristics of the Syntactic Model of Formation of Derivative Prepositions", Vestnik of
St. Petersburg State University. Ser. 9. Issue 3:105-114

[4] Valgina, N., Rosenthal, D., Fomina, M. 2002. Modern Russian: Textbook / Edited by Valgina N. Moscow: Logos, $528 \mathrm{p}$.

[5] Vinogradov, V. 2001. Russian language (grammatical doctrine of the word). Edited by Zolotova G., 4th ed. Moscow: Russkiy yazyk., 720 p.

[6] Vinogradova, E. 2013. "Motivated prepositions and analogues of prepositions: ways of grammaticalization". Edited by Vinogradova E. Bulletin of Moscow University. Series 9. Philology. no. 4: 138-163.

[7] Vinogradova, E., Chekalina, V. 2004. "On the issue of the grammar of the Russian preposition". Article 1. First results. The concept of a paradigm of a preposition. Vestnik of Moscow State University. Series 9. Philology. no. 5: 7-35.

[8] Vinogradova, E., Chekalina, V. 2006. "On the issue of the grammar of the Russian preposition". Article 2. Synonymy, antonymy of prepositional units. Vestnik of Moscow State University. Series 9. Philology. no. 2. 18-37.

[9] Vsevolodova, M. 2008. "Typology of the Slavic preposition. Systematic: categories and paradigms". XIV international congress of Slavists. Slavic linguistics. Linguistics. Moscow. Indrik: 119-144.

[10] Vsevolodova, M. 2005. On the issue of methodologies and methods of linguistic analysis (on the example of categories of spatial, temporal and causal relations) (first article). Vestnik of Moscow State University. Series 9. Philology. no. 1: 22-49

[11] Gavrilenko, V. 2013. "Semantic-syntactic features of derivative prepositions "in the form of" and "in the type of". Philological sciences. Issues of theory and practice. Tambov. Gramota. no. 3 (21): (in 2 volumes), Vol. I.: $37-40$.

[12] Galaktionova, I. 2007. Preposition: pre-position and post-position [Electronic resource]. Section X. Functional units of the Russian language. Proceedings of the III International Congress of Russian Language Researchers "Russian Language: Historic Fates and Modernity" Moscow: Moscow State University: 272-273. URL: http://www.philol.msu.ru

[13] Galstyan, S. 2015. Grammar and lexis in the preposition (based on the Spanish language). Ibero-American notebooks. no. 2 (8): 72-76.

[14] Dal, V. 1994. Thesaurus of the living Great Russian language: In 4 vol. Moscow: Progress, Vol. 4. p. 199.

[15] Eremin, A. 2010. On the issue of the preposition as part of speech. Russian language in the school. no. 6: 85-89.

[16] Kiyamova, M. 2016. Criteria for differentiation of variants of derivative prepositions (based on the works of A. Pushkin). Vestnik of Volgograd state University. Series 2, Linguistics. Vol. 15. no 2: $144-151$.

[17] Klobukov, E. 2007. Section X. Functional units of the Russian language. Proceedings of the III International Congress of Russian Language Researchers "Russian Language: Historic Fates and Modernity" Moscow: Moscow State University: 277- 278. Access: http://www.philol.msu.ru 
[18] Kravchenko, N. 2001. Semantic and text - forming functions of Russian prepositions (based on the language of fiction and the media): dissertation thesis. Krasnodar, 273 p.

[19] Lebedeva, Ya. 2007. The actualization paradigm of the preposition [Electronic resource]. Proceedings of the III International Congress of Russian Language Researchers "Russian Language: Historic Fates and Modernity" Moscow: Moscow State University: 280-281. URL: http://www.philol.msu.ru

[20] MAC: (Small Academic Dictionary of the Russian language). 1999. In 4 volumes. Edited by Evgenieva A. 4 th ed., Moscow: Russkiy yazyk, Polygraphic resources, Vol. 3. $795 \mathrm{p}$.

[21] Meshchaninov, I. 1978. Members of the sentence and parts of speech. Academy of sciences of SSSR. Department of Literature and Language. Leningrad: Nauka, 386 p.

[22] Ozhegov, S., Shvedova, N. 1999. Thesaurus of the Russian language. Moscow: Azbukovnik: p. 202.

[23] Pankov, F. 2004. On the issue of operational methods for verifying categorial words in the Russian language. Moscow: Publishing House of Moscow State University: 235-236.

[24] Pekar, V. 2000. Semantics of the prepositions of vertical juxtaposition in the cognitive aspect (on the material of the English prepositions 'above' and 'over' and the Russian preposition 'over'): the author's abstract to dissertation thesis. Ufa, $24 \mathrm{p}$.

[25] Peshkovsky, A. 1956. Russian syntax in scientific coverage. Moscow: Uchpedgiz, $511 \mathrm{p}$.

[26] Prusakova, E. 2002, System of derivative prepositions of the modern Russian language: abstract to dissertation thesis. Bishkek, 28 p.

[27] Rogozhnikova, R. 1991. Dictionary of the equivalents of the word. Adverbial, functional, modal unity. Moscow: Russkiy yazyk: 254 p.

[28] Russian grammar: 1980. In 2 volumes. Vol. 1: Phonetics. Phonology. Stress. Intonation. Introduction to morphemic. Word formation. Morphology. Moscow: Nauka, 784 p.

[29] Ushakov, D. 2000. Thesaurus of the Russian language: In 4 volumes. Moscow: Russkiye slovari. Vol. 4. p. 201.

[30] Cherkasova, E. 1967. The transition of full-valued words into prepositions. Moscow: Nauka, 280 p.

[31] Sheremeteva, E. 2008. Denominative relatives of the modern Russian language. Semantico-syntactic etudes. Monograph.Vladiivostok: Far East University Publishing House, $236 \mathrm{p}$.

[32] Shmykalyova, I. 2015. Derivative prepositions 'in connection with', 'for the reason of' and their text paradigms in the aspect of speech competition: abstract to dissertation thesis. Nizhny Novgorod, $26 \mathrm{p}$. 